ВІСНИК

ОДЕСЬКОГО НАЦІОНАЛЬНОГО МОРСЬКОГО УНІВЕРСИТЕТУ
HERALD

OF THE ODESSA NATIONAL

MARITIME UNIVERSITY № 1 (61), 2020

УДК 666.972

DOI 10.47049/2226-1893-2020-1-154-166

\title{
ЩОДО РОЗРОБКИ КОМПЛЕКСНОЇ МОДЕЛІ «КАТЕГОРІЯ ДЕФЕКТУ - СКЛАД МОДИФІКОВАНОГО БЕТОНУ» ДЛЯ РЕМОНТНО-ВІДНОВЛЮВАЛЬНИХ РОБІТ МОРСЬКИХ ПОРТОВИХ ГІДРОТЕХНІЧНИХ СПОРУД ПАЛЬОВОГО ТИПУ
}

Ю.О. Рубцова

асистент кафедри Автомобільних доріг та аеродромів

Одеська державна академія будівництва та архітектури

Анотація. Проаналізовані фактичні умови роботи і результати інженерних обстежень конструкиій морських портових гідротехнічних споруд пальового типу. Сформулювана системна модель «категорія дефекту - склад модифікованого бетону», що дозволяє дослідити $i$ впровадити оптимальні склади модифікованих бетонів для ремонтновідновлювальних робіт наявних конструктивних елементів в залежності від ступеня їх пошкодженості, що характеризується запропонованими «Модулями пошкоджуваності бетону».

Ключові слова: пальові естакади, технічний стан, категорія дефектів, модулі пошкоджуваності бетону, оптимальні склади, модифіковані бетони.

УДК 666.972

DOI 10.47049/2226-1893-2020-1-154-166

К ВОПРОСУ РАЗРАБОТКИ КОМПЛЕКСНОЙ МОДЕЛИ «КАТЕГОРИЯ ДЕФЕКТА - СОСТАВ МОДИФИЦИРОВАННОГО БЕТОНА» ДЛЯ РЕМОНТНО-ВОССТАНОВИТЕЛЬНЫХ РАБОТ МОРСКИХ ПОРТОВЫХ ГИДРОТЕХНИЧЕСКИХ СООРУЖЕНИЙ СВАЙНОГО ТИПА

Ю.А. Рубцова

ассистент кафедры Автомобильных дорог и аэродромов

Одесская государственнная академия строительства и архитектуры

Аннотация. Проанализированы фактические условия работы и результаты инженерных обследований конструкций морских портовых гидротехнических сооружений эстакадного типа.

(C) Рубцова Ю.О., 2020 
Сформулирована системная модель «категория дефекта состав модифицированного бетона», что позволяет исследовать и внедрить оптимальные составы модифицированных бетонов для ремонтновосстановительных работ существующих конструктивных элементов в зависимости от степени их поврежденности, которая характеризуется предложенными «Модулями повреждаемости бетона».

Ключевые слова: свайные эстакады, техническое состояние, категория дефектов, модули повреждаемости бетона, оптимальные составы, модифицированные бетоньл.

UDC 666.972

DOI 10.47049/2226-1893-2020-1-154-166

\title{
REGARDING DEVELOPMENT OF A SYSTEM MODEL «DEFECT CATEGORY - COMPOSITION CONCRETE» FOR REPAIR AND RECOVERY WORKS OF MARINE HYDRAULIC STRUCTURES OPEN JETTY TYPE
}

\author{
YU. Rubtsov
}

assistant of the Department of Roads and Aerodroms

Odessa State Akademy of Civil Engineering and Architecture, Ukraine

Abstract. The actual working conditions and the engineering surveys results of seaport hydraulic structures of pile pier type are analyzed. It is shown that reinforced concrete structural elements made according to typical design solutions using «standard» concrete (ie without the use of complex chemical modifiers, mineral fillers or dispersed fiber reinforcement, etc.), because of complex multifactorial conditions of work can not guarantee the design strengths throughout the regulatory life span.

The system model "defect category - composition of modified concrete» was formulated. It will allows investigating and implementing the optimal modified concrete composition for repair work of the available structural elements depending on the degrees of damage.

In addition to the regulatory requirements, it is suggested to classify concrete damage by depth (up to $5 \mathrm{~cm}, 5-20 \mathrm{~cm}$, more than 20cm). Accordingly, the concept of «Damage Modules of Concrete - Ordinary, Limited and Critical» was introduced.

Practical recommendations on the selection of optimal compositions of modified concrete, depending on the «Module of concrete damage» bearing elements of the investigated structures. In this case, the use of modified concrete will provide a number of technological advantages: accelerated timing of dismantling formwork due to the acceleration of the concrete 
hardening term; improved workability of the concrete mix; possibility of repair work by the shotcrete method without the use of formwork, etc.

Keywords: pile pier, technical condition, category of defects, damage modules of concrete, optimal compositions, modified concrete.

Вступ. На балансі Адміністрації морських портів України знаходиться близько 260 вантажних причалів протяжністю не менш 43км. В загальній довжині причалів близько 57,5 \% складають естакадні споруди, $34,5 \%$ - споруди типу «больверк», 8,0 \% - споруди гравітаційного типу. Таким чином, майже 25 км причалів - це естакадні споруди на залізобетонних палях (в основному, чотирьох-, п'яти- і шестирядні на залізобетонних призматичних опорах перерізом $45 \times 45 \mathrm{~cm}$, рідше $40 \mathrm{x} 40 \mathrm{~cm}$ ). Специфіка цих споруд перш за все полягає в тому, що естакади включають несучі конструктивні елементи (палі, бортові балки, плити ростверку, тилове сполучення), розташовані в різних зонах - над/під водою, зоні змінного горизонту води, в грунті. Як правило, ці багатоелементні споруди, найбільш ушкоджувані протягом нормативного терміну служби. В свою чергу, значний фізичний знос несучих конструкцій - один 3 основних факторів, що стримують збільшення вантажопотоку через морські порти України та здійснюють істотний вплив на безпеку їх експлуатації.

Комплексний аналіз результатів інженерних обстежень морських портових гідротехнічних споруд естакадного типу (МПГТСЕТ) показує, що при фактичному терміні експлуатації 10-40 років, вже на початкових стадіях, в абсолютній більшості споруд, залізобетонні конструктивні елементи мають ряд характерних ушкоджень - у вигляді тріщин шириною розкриття більше 3мм, руйнувань захисного шару з корозією арматури, відколів бетону та ін. Все це свідчить про те, що залізобетонні конструктивні елементи, виготовлені за типовими проектними рішеннями iз застосуванням «стандартного» бетону (тобто без застосування комплексних хімічних модифікаторів, мінеральних наповнювачів чи дисперсного армування фіброволокном та інш.), через складні багатофакторні умови роботи (коливання температури повітря від $-40^{\circ}$ до $+50{ }^{\circ} \mathrm{C}$, агресивне середовище, вплив знакозмінних навантажень, льодові та динамічні дії тощо), не можуть гарантувати проектні значення міцності та довговічність протягом усього нормативного терміну служби. Використання модифікованих бетонів в замін «стандартних»- один 3 ефективних напрямків підвищення міцності і довговічності морських портових гідротехнічних споруд, у т.ч. естакадного типу.

Таким чином, потрібно розробити системний науково-обгрунтований підхід до ремонтно-відновлювальних робіт МПГТСЕТ, що дозволить запобігти передчасному фізичному зносу залізобетонних несучих конструкцій. 
У данній статті за результатами комплексного аналізу сформулювана системна модель «категорія дефекту - склад модифікованого бетону», що дозволяє дослідити і впровадити оптимальні склади модифікованих бетонів для ремонтно-відновлювальних робіт наявних конструктивних елементів МПГТСЕТ в залежності від ступеня їх пошкодженості, що характеризується запропонованими «Модулями пошкоджуваності бетону».

На першому етапі дослідження проаналізовано фактичні умови роботи МПГТСЕТ. Абсолютна більшість досліджуваних споруд збудовано в період 1953-90 рр. за типовими проектними рішеннями [1-4]. При цьому конструкції розраховувались за наступними умовами:

- захищені акваторії з висотою хвилі - не більше 1,0 м;

- товщина нерухомого льоду - не більше 0,6 м;

- нормативна швидкість вітру - 27 м/с;

- інженерно-геологічні умови основи - грунти, що стискаються, підлягають прорізці свайними опорами, 3 нормативним кутом внутрішнього тертя $\varphi=25^{\circ}, \mathrm{c}=0$;

- температурний режим 3 максимальною розрахунковою температурою $+34{ }^{\circ} \mathrm{C}$ мінімальною $-21{ }^{\circ} \mathrm{C}$ при перепаді температур не більше $20{ }^{\circ} \mathrm{C}$;

- сейсмічність - не вище 6 балів;

- ступінь агресивної дії «води - середовища» на бетон конструкції при нормальній щільності бетону - середня (бікарбонатна лужність не перевищує $1,4\left(4^{\circ}\right)$ - 0,7(2 $\left.{ }^{\circ}\right)$ мг-экв/л (град)) для корозії I виду.

Для оцінки ступеня пошкоджуваності бетону конструкцій МПГТСЕТ за участю автора проаналізовано матеріали інженерних обстежень, виконаних ДП «ЧОРНОМОРНДІПРОЕКТ» у 2005-19pp. у портах Чорноморсько-Азовського та Дунайського басейнів - Одеса, Миколаїв, Ізмаїл, Бердянськ, Маріуполь, Чорноморськ, Херсон, Південий та інш. (табл. 1) [5].

Аналіз результатів інженерних обстежень споруд проводився на підставі звітів за причалами перелічених вище портів. Зазначені порти являють собою три характерних приклади об'єктів з різними природнокліматичними умовами. Так, вода Ізмаїльського порту - переважно прісна, оскільки порт розташований на річці Дунай. Разом з тим, місце розташування порту має більш високу сейсмічну активність 8-9 балів [6] в порівнянні 3 умовами в порту Одеса: 7-8 балів і солоною морською водою: (26,9 г $\mathrm{NaCl}+3,4$ г $\mathrm{MgCl} 2+2,5$ г MgSO4 + 1,2 г CaSO4). Мінімальна температура в порту Одеса складає $-27{ }^{\circ} \mathrm{C}$. Тоді як порт Поті розташовується в субтропічному поясі, де сніг випадає рідко (8-10 днів у році) і висота снігового покриву рідко досягає 20 см. Мінімальна температура в порту Поті складає $-11{ }^{\circ} \mathrm{C}$. Агресивні властивості води визначає міра їі мінералізації, жорсткість, а також кислотності і лужності. Морська (океанська) вода може містити до 35 міліграм/л солей, 3 них: 
хлористого натрію $78 \%$, хлористого магнію $11 \%$, сірчанокислих магнію, кальцію і калію відповідно до 4,7; 3,6; 2,5 \%. Вміст солей в морях України, завдяки опрісненню річковими водами, помітно знижується: в Чорному морі - до 10-18 г/л, в Азовському - до 9-12 г/л.

На другому етапі досліджень проведена оцінка результатів інженерних обстежень за якісними та кількісними показниками, а саме: про-ектні характеристики кожного конструктивного елементу (габаритні розміри, зони розташування, фізико-механічні властивості бетону тощо), а також види, розміри та природа походження дефектів (табл. 1).

Таблиия 1

Перелік досліджуваних причалів естакадного типу в морських портах України (2005-2019 рр.)

\begin{tabular}{|l|c|}
\hline \multicolumn{1}{|c|}{ Назва морського порту } & Причальні споруди \\
\hline Білгород-Дністровський & № 8, пр.1 (з/п Бугаз) \\
\hline Бердянський & № 1 (уч. 1), № 2 (уч. 2), № 5 (уч. 1) \\
\hline Ізмаїльський & № 4, 7, 8,12,13, причал портофлота, 14 \\
\hline Маріупольський & № 9, 10, 11, 12, 13, 14 \\
\hline Миколаївський & № 1н, 24, 25, 26, 37-38 (пірс № 3), 123, \\
\hline Одеський & № 44, 45, 46, 47 \\
& № 1, 9, 10, 11 (ПК0-ПК6+0,1 м), \\
& № 14 (ПК1+5,2 м-ПК28+8,6 м), № 18 \\
(ПК6+8,5 м-ПК16+8,5 м), № 20 \\
\hline Херсонський & № 2, 34, 5, 6 \\
\hline Чорноморський & № 2, 9, 10 (уч. 1, 3), 11, 12, 14, 15, 16, 17, \\
(Ілічівський) & 18, 19, 20, 21, 22, 23 \\
\hline Південний (Южний) & № 1, 2, 3, 4, 39 \\
\hline
\end{tabular}

Встановлено, що фактичний термін служби абсолютної більшості досліджуваних споруд (73 \%) перевищує 30 років чи наближається до граничного (50 років). Нижче приведені узагальнені дані за останні роки щодо фактичних термінів служби МПГТСЕТ в морських портах України.

Разом 3 тим, не дивлячись на те, що обстежувані гідротехнічні споруди знаходяться у різних природно-кліматичних районах, зафіксовані дефекти бетону принципово схожі за типами, розмірами та зонами розташування. 
a)

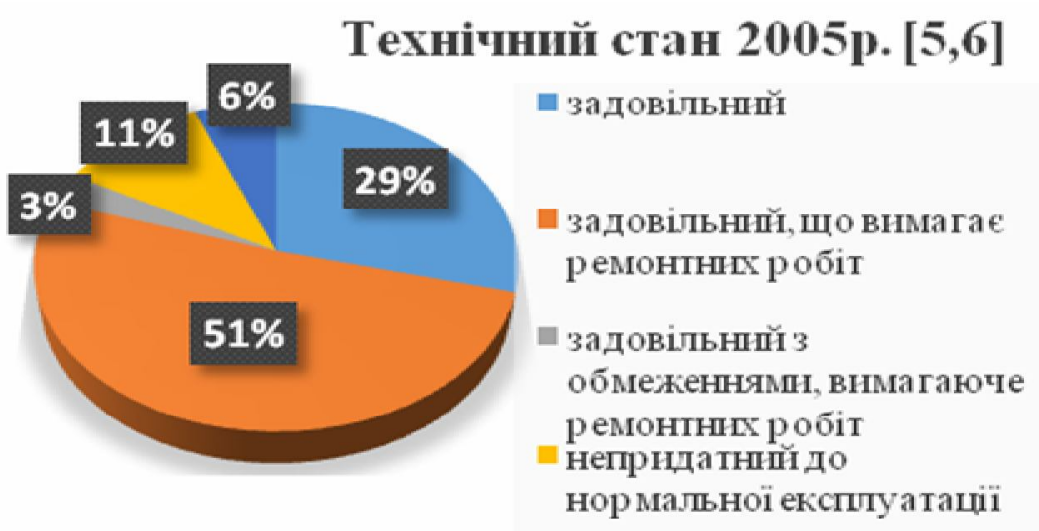

б)

\section{Технічний стан 2019p. $[5,6]$}

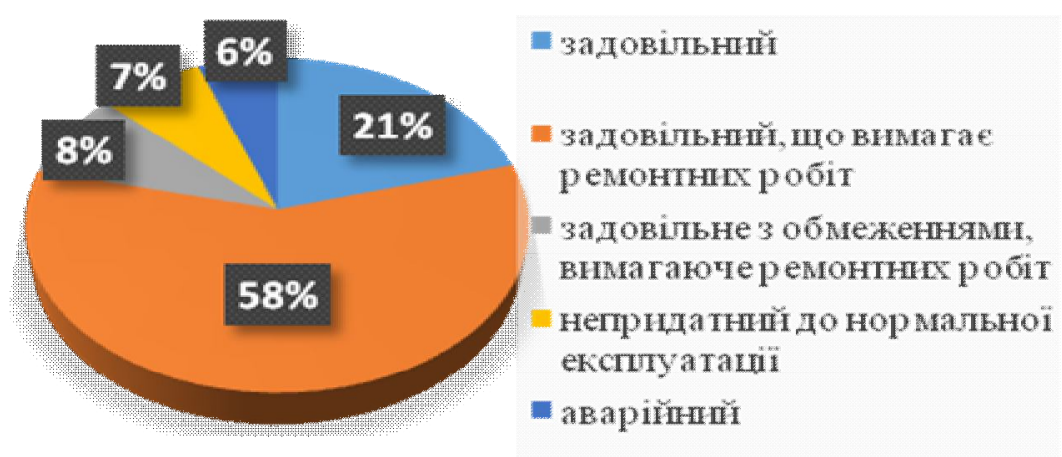

Рис. 1. Фактичний технічний стан причалів естакадного типу на залізобетонних палях:

a) $2005 p$.; б) $2019 p$. 


\begin{tabular}{c|c} 
ВІСНИК & HERALD \\
ОДЕСЬКОГО НАЦІОНАЛЬНОГО & OF THE ODESSA NATIONAL \\
МОРСЬКОГО УНІВЕРСИТЕТУ & MARITIME UNIVERSITY \\
№ 1 (61), 2020 & № 1 (61), 2020 \\
\hline \hline
\end{tabular}

a)

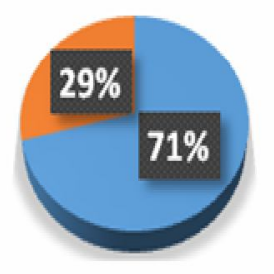

\section{-}

експлуатації

без ремонту в період

експлуатацін

б)

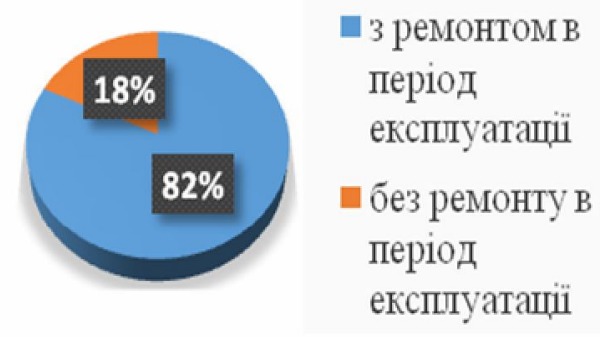

Рис. 2. Динаміка виконання ремонтно-відновлювальних робіт на причалах естакадного типу на залізобетонних палях:

a) 2005 p.; б) $2019 \mathrm{p}$.

До того ж протягом останніх 40 років узагальнення та класифікація дефектів під час інженерних обстежень залізобетонних конструкцій МПГТСЕТ проводилися з єдиною метою - оцінка технічного стану.

За результатами комплексного аналізу фактичного технічного стану МПГТСЕТ встановлено, що ремонтні роботи, в абсолютній більшості не гарантують працездатність відповідних залізобетонних конструкцій.

Таким чином, отримані результати досліджень є безумовним підтвердженням, що використані «стандартні» бетони не можуть гарантувати проектні значення міцності та довговічність протягом усього нормативного терміну служби споруд.

На третьому етапі на основі комплексного аналізу результатів обстеження МПГТСЕТ та узагальнення зафіксованих дефектів розроблена класифікаційна модель пошкоджуваності бетону. Основні результати досліджень надані у вигляді зведених таблиць фактичного технічного стану бетону конструкцій (табл. 2). 
Таблиия 2

Узагальнені показники пошкодження несучих конструкиій МПГТСЕТ

\begin{tabular}{|c|c|c|c|}
\hline \multicolumn{4}{|c|}{ Пошкоджуваність нижньої поверхні плит ростверку: } \\
\hline $\begin{array}{c}\text { Глибина } \\
\text { ушкоджень бетону }\end{array}$ & до $5 \mathrm{~cm}$ & $5-20 \mathrm{~cm}$ & більше 20 см \\
\hline Кількісний показник & $40 \%$ & $40 \%$ & $20 \%$ \\
\hline \multicolumn{4}{|c|}{ Бортова балка. Зовнішні ушкодження (з боку моря): } \\
\hline $\begin{array}{c}\text { Глибина } \\
\text { ушкоджень бетону }\end{array}$ & до $5 \mathrm{~cm}$ & $5-15 \mathrm{~cm}$ & більше 15 см \\
\hline Кількісний показник & $30 \%$ & $60 \%$ & $10 \%$ \\
\hline \multicolumn{4}{|c|}{ Бортова балка. Місця сполучення: } \\
\hline $\begin{array}{c}\text { Глибина } \\
\text { ушкоджень бетону }\end{array}$ & до 5 см & $5-10 \mathrm{~cm}$ & більше 10 см \\
\hline Кількісний показник & $60 \%$ & $30 \%$ & $10 \%$ \\
\hline \multicolumn{4}{|c|}{ Призматичні палі. Зона змінного горизонту води: } \\
\hline $\begin{array}{c}\text { Глибина } \\
\text { ушкоджень бетону }\end{array}$ & до 5 см & $5-10 \mathrm{~cm}$ & більше 10 см \\
\hline Кількісний показник & $60 \%$ & $30 \%$ & $10 \%$ \\
\hline \multicolumn{4}{|c|}{ Призматичні палі. Вузол контакту палі з верхньою будовою: } \\
\hline $\begin{array}{c}\text { Глибина } \\
\text { ушкоджень бетону }\end{array}$ & до 5 см & $5-10 \mathrm{~cm}$ & $\begin{array}{c}\text { Порожнини між палею } \\
\text { і верхньою надбудовою } \\
(10-30 \mathrm{~cm})\end{array}$ \\
\hline Кількісний показник & $50 \%$ & $40-45 \%$ & $3-5 \%$ \\
\hline
\end{tabular}

Примітка: Вказані значення наведено за результатами комплексного аналізу результатів обстеження МПГТСЕТ [5].

За результатами дослідження найуразливіші залізобетонні конструктивні елементи: палі в змінному горизонті води, бортові балки, нижня поверхня верхньої будови і фасадну частину масивів тилового сполучення. При цьому запропонована узагальнена кількісна класифікація характерних дефектів бетону споруд, що відрізняється більш наочністю та практичністю у порівнянні з прийнятими нормативними показниками [7].

Таким чином, у доповнення до нормативних вимог [7; 8], запропоновано класифікувати пошкодження бетону МПГТСЕТ за глибиною (до $5 \mathrm{~cm}, 5-20 \mathrm{~cm}$, більш $20 \mathrm{~cm}$ ). Відповідно введено поняття «Модулів пошкоджуваності бетону» 3 наступною градацією (табл. 3):

- при глибині пошкоджень до 5 см (ординарний модуль ушкоджуваності);

- при глибині пошкоджень 5-20 см (граничний модуль);

- при глибині пошкоджень більше 20 см (критичний модуль). 
При цьому:

- ординарний - впливає на довговічність конструкцій;

- граничний - впливає на довговічність та несучу здатність;

- критичний - свідчить про те, що конструкція не ремонтно-придатна, тобто потрібна повна заміна, підсилення або реконструкція.

Таблиия 3

Классифікаиія «Модулів пошкодженості бетону» МПГТСЕТ

\begin{tabular}{|l|c|c|c|}
\hline $\begin{array}{c}\text { Основні види } \\
\text { технічного } \\
\text { стану споруди } \\
\text { [7] }\end{array}$ & $\begin{array}{c}\text { Дефекти } \\
\text { та ступень } \\
\text { пошкодження } \\
\text { бетону [7] }\end{array}$ & $\begin{array}{c}\text { Глибина } \\
\text { пошкодження }\end{array}$ & $\begin{array}{c}\text { Модуль } \\
\text { пошкоджуваності } \\
\text { бетону }\end{array}$ \\
\hline Задовільне & Малозначні & до 5 см & Ординарний \\
\hline $\begin{array}{l}\text { Задовільне } \\
\text { з обмеженнями }\end{array}$ & $\begin{array}{c}\text { Малозначні } \\
\text { Значні }\end{array}$ & 5 см & Ординарний \\
\hline Непридатне & Значні & $5-20 \mathrm{~cm}$ & Граничний \\
\hline Аварійне & Критичні & більше 20 см & Граничний \\
\hline
\end{tabular}

Примітка: Читати разом з таблищею 2.

На четвертому етапі сформулювана системна модель «категорія дефекту - склад модифікованого бетону», що дозволяє розробити і впровадити оптимальні склади таких бетонів для ремонтновідновлювальних робіт МПГТСЕТ.

На основі попередніх пошукових експериментальних досліджень [9], на відміну від «стандартних» гідротехнічних бетонів, запропоновані модифіковані бетони. У склад досліджуваних модифікованих бетонів входить:

- добавка протиморозної дії (нітрат кальцію технічний), мінеральний наповнювач (мікрокремнезем конденсований) та дисперсне арму-вання (поліпропіленовою фіброю Baucon) - для сумішей без крупного заповнювача;

- добавка комплексної дії (полікарбоксилат Coral ExpertFix12) та дисперсне армування (поліпропіленовою фіброю Baucon) - для сумішей 3 фракцією крупного заповнювача до 10мм.

Таким чином, в результаті виконаних досліджень для ремонтновідновлювальних робіт МПГТСЭТ рекомендовані:

- модифіковані дрібнозернисті фібробетони без крупного заповнювача, що включає добавку протиморозної дії нітрат кальцію 
технічний, мінеральний наповнювач мікрокремнезем конденсований та дисперсне армування поліпропіленовою фіброю Baucon;

- модифіковані дрібнозернисті фібробетони (фракція крупного заповнювача до 10 мм) що включають у складі добавку добавка комплексної дії полікарбоксилат Coral ExpertFix12 та дисперсне армування поліпропіленовою фіброю Baucon.

Це дозволить забезпечити підвищені міцністні та інші основні властивості бетону, що використовується для усунення дефектів:

- міцність при стиску у віці 3 діб від 8,0 МПа до 45,0 МПа

- міцність при стиску у віці 28 діб від 40,0 Мпа до 80,0 МПа

- міцність на розтяг при згині від 7,5 МПа до 9,0 МПа

- морозостійкість від F200 до F600;

- воднепроникність від W6 до W12;

- стиранність від 0,3 до 0,5 г/ $\mathrm{cm}^{2}$.

- адгезія (міцність зчеплення з основою) від 0,8 до 1,0 МПа.

До того ж модифіковані бетони мають низку технологічних переваг:

- прискорені строки демонтажу опалубки за рахунок прискорення строків твердіння бетону

- покращена удобоукладуваність бетоної суміші;

- можливість проведення ремонтних робіт методом торкрету без використання опалубки тощо.

За результатами досліджень розроблені практичні рекомендації 3 вибору типу модифікованого бетону для ремонтно-відновлювальних робіт конструкцій МПГТСЕТ з урахуванням запропонованих «Модулів пошкоджуваності бетону» (табл. 5).

\section{Висновки}

1. Виконано комплексний аналіз фактичного технічного та деформативного станів МПГТСЕТ у портах Чорноморськ, Одеса, Південний, Ізмаїл та інш., що експлуатуються в різних природнокліматичних умовах. На підставі дефектних відомостей зафіксовані пошкодження узагальнені та класифіковані за кількісними та якісними показниками. При цьому вперше введено поняття «Модулів пошкоджуваності бетону» 3 наступною градацією:

- ординарний - впливає на довговічність конструкцій;

- граничний - впливає на довговічність та несучу здатність;

- критичний - свідчить про те, що конструкція не ремонтнопридатна, тобто потрібна повна заміна, підсилення або реконструкція. дефектів.

Кожен $з$ модулів характеризується різною глибиною і площею 
Вибор типу модифікованого бетону

з урахуванням «Модулів пошкоджуваності бетону»

\begin{tabular}{|c|c|c|c|c|}
\hline $\begin{array}{c}\text { Основні види } \\
\text { технічного } \\
\text { стану споруди } \\
\text { [7] }\end{array}$ & $\begin{array}{c}\text { Дефекти } \\
\text { та ступень } \\
\text { пошкодження } \\
\text { бетону [7] }\end{array}$ & $\begin{array}{c}\text { Глибина } \\
\text { пошкод- } \\
\text { ження }\end{array}$ & $\begin{array}{c}\text { Модуль } \\
\text { пошкоджув } \\
\text { аності }\end{array}$ & $\begin{array}{c}\text { Рекомендації } \\
\text { до відновлення } \\
\text { бетону }\end{array}$ \\
\hline Задовільне & Малозначні & до 5 см & Ординарний & $\begin{array}{l}\text { Модифіковані } \\
\text { дрібнозернисті } \\
\text { бетони без } \\
\text { крупного запов- } \\
\text { нювача } \\
\end{array}$ \\
\hline \multirow{2}{*}{$\begin{array}{l}\text { Задовільне } 3 \\
\text { обмеженнями }\end{array}$} & Малозначні & до $5 \mathrm{~cm}$ & Ординарний & $\begin{array}{l}\text { Модифіковані дріб- } \\
\text { нозернисті } \\
\text { фібробетони без } \\
\text { крупного } \\
\text { заповнювача. }\end{array}$ \\
\hline & Значні & $5-20 \mathrm{~cm}$ & Граничний & $\begin{array}{l}\text { Модифіковані } \\
\text { дрібнозернисті } \\
\text { фібробетони } \\
\text { (фракція крупного } \\
\text { заповнювача до } 10 \\
\text { мм) }\end{array}$ \\
\hline Непридатне & Значні & $5-20 \mathrm{~cm}$ & Граничний & $\begin{array}{l}\text { Модифіковані } \\
\text { дрібнозернисті } \\
\text { фібробетони } \\
\text { (фракція крупного } \\
\text { заповнювача до } 10 \\
\text { мм) }\end{array}$ \\
\hline Аварійне & Критичні & $\begin{array}{l}\text { більше } \\
20 \mathrm{~cm}\end{array}$ & Критичний & $\begin{array}{l}\text { Виконання ремонту } \\
\text { недоцільно, конст- } \\
\text { рукція потребує } \\
\text { заміни }\end{array}$ \\
\hline
\end{tabular}

Примітка: Читати разом з таблицями 2; 3.

2. Розроблено практичні рекомендації стосовно підбору оптимальних складів модифікованих бетонів у залежності від «Модулів пошкоджуваності бетону» несучих елементів МПГТСЕТ: ординарного, граничного та критичного. При цьому використання модифікованих бетонів дозволить забезпечити низку технологічних переваг: прискорені строки демонтажу опалубки за рахунок прискорення строків твердіння бетону; покращена удобоукладуваність бетоної суміші; можливість 
ВІСНИК

ОДЕСЬКОГО НАЦІОНАЛЬНОГО

МОРСЬКОГО УНІВЕРСИТЕТУ

№ 1 (61), 2020
HERALD

OF THE ODESSA NATIONAL

MARITIME UNIVERSITY

№ 1 (61), 2020

проведення ремонтоних робіт методом торкрету без використання опалубки тощо.

3. Розроблені рекомендації використовуються ДП «ЧОРНОМОРНДІПРОЕКТ» та іншими приватними структурами при складанні проектно-кошторисної документації на капітальний ремонт об'єктів в портах Південний, Одеса, Чорноморськ, Ізмаїл.

4. В подальшому необхідно:

- розробити технічні регламенти (рекомендації) з використання модифікованих бетонів при ремонтно-відновлювальних роботах МПГТСЕТ;

- удосконалити технологію ремонтно-відновлювальних робіт в залежності від зони розташування того чи іншого конструктивного елемента МПГТСЕТ;

- додатково виконати дослідження щодо використання модифікованих бетонів при будівництві нових МПГТСЕТ, а також інших конструк-тивних типів портових ГТС.

\section{СПИСОК ЛІТЕРАТУРИ}

1. Типовий проект пальових залізобетонних набережних естакад зі збірним ростверком (для глибин 9,75 м, 8,25 м та 7,25 м) (інв. № 14686). Одеса, 1958. (ЧорноморНДІпроект).

2. Типовий проект № 46264 збірних залізобетонних набережних естакад на палях для глибин 11,5 м та 9,75 м. Москва, 1954.

3. Типовий проект № 5-05-207 залізобетонна набережна естакада з розширеним кроком на призматичних палях перерізом 45х45 см (глиб. 11,5 м) (інв. № 23322). Одеса, 1965.

4. Портові набережні естакади на залізобетонних палях $45 \times 45$ см. Серія 3.504.1-22. Випуск 0». Одеса, 1986.

5. Матеріали контрольно-інспекторських обстежень та паспортизачії причалів в портах: Одеса, Іллічівськ, Миколаїв, Южний, Херсон, Севастополь, Білгород-Дністровськ, Ізмаїл, Рені, Скадовськ, Бердянськ, Маріуполь, Поті // Звітна документаиія / ДП «ЧОРНОМОРНДІПРОЕКТ》, 2005-2019 p.

6. ДБН В.1.1-12-2014 Будівництво у сейсмічних районах Украйни НД 31.002.3-2003. Інструкиія з інженерного обстеження $i$ паспортизачії портових гідротехнічних споруд / Одеса, 2003.

7. РД 31.003.3-2005. Правила технічної експлуатації портових гідротехнічних споруд / Одеса, 2005.

8. Рубиова Ю.А. Модифицированные бетоны для ремонтновосстановительных работ свайных эстакад морских портовых гидротехнических сооружений / Ю.А. Рубиова // Scientific and technical journal "Energy». ISSN 1512-0120. Georgian Technical University. Tbilisi, 2018. 4(88), p.86-93. 


\section{REFERENCES}

1. Typical project of pile reinforced concrete embankment trestles with precast grating (for depths of 9,75 $\mathrm{m}, 8,25 \mathrm{~m}$ and 7,25 m) (ref. \# 14686). Odessa, 1958. ("CHERNOMORNDIPROEKT»).

2. Typical project No. 46664 of precast concrete embankment trestles on piles for depths of 11,5 $\mathrm{m}$ and 9,75 m. Moscow, 1954.

3. Typical project №5-05-207 reinforced concrete embankment trestle with extended step on prismatic piles with a cross section of $45 \times 45 \mathrm{~cm}$ (depth 11.5m) (ref. No. 23322). Odessa, 1965.

4. Harbor embankments on reinforced concrete piles $45 \times 45 \mathrm{~cm}$ Series 3.504.1-22. Issue 0. Odessa, 1986.

5. Materials of inspection and certification of pile piers in ports: Odessa, Ilichevsk, Mykolayiv, Yuzhny, Kherson, Sevastopol, Belgorod-Dnestrovsk, Izmail, Reni, Skadovsk, Berdyansk, Mariupol, Poti / Reporting // SC "CHERNOMORNDIPROEKT》 2005-2019.

6. DBN B.1.1-12-2014 Construction in seismic regions of Ukraine.

7. ND 31.002.3-2003. Instruction on engineering inspection and certification of port hydraulic structures / Odessa, 2003.

8. $R D$ 31.003.3-2005. Rules for the technical operation of port hydraulic structures / Odessa, 2005.

9. Rubtsova Yu.A. Modified Concretes for Repair Works of Marine Port Hydraulic Pile Piers / Yu.A. Rubtsova // Scientific and technical journal «Energy». ISSN 1512-0120. Georgian Technical University. Tbilisi, 2018. 4 (88), p.86-93.

Стаття надійшла до редакиії 05.03.20

Посилання на статтю: Рубцова Ю.О. Щодо розробки комплексної моделі «Категорія дефекту - склад модифікованого бетону» для ремонтновідновлювальних робіт морських портових гідротехнічних споруд пальового типу // Вісник Одеського національного морського університету: Зб. наук. праць, 2020. № 1(61). C. 154-166. DOI 10.47049/2226-1893-2020-1-154-166.

Article received 05.03.20

Reference a JournalArtic: Rubtsov, Yu. Regarding development of a system model «Defect category - composition concrete» for repair and recovery works of marine hydraulic structures open jetty type. 1(61), 154-166 // Herald of the Odessa national maritime university. DOI 10.47049/ 2226-1893-2020-1-154-166. 